\title{
THE CONTROL OF FALSE ADVERTISING UNDER THE WHEELER-LEA ACT $\dagger$
}

\author{
Mirton HaNDLER*
}

The new Federal Food, Drug and Cosmetic Act, ${ }^{1}$ like the Act of $1906,{ }^{2}$ does not penalize and, indeed, has no application to the false and misleading advertising of food, drugs and cosmetics. Control over such advertising is continued in the Federal Trade Commission whose powers, ${ }^{3}$ however, have been augmented by the WheelerLea Amendments ${ }^{4}$ enacted in March, 1938. Regulation of advertising is not a new function for the Commission. Since its establishment, the Commission has endeavored to suppress improper advertising in all trades and industries engaged in interstate commerce. The recent amendments are designed to supplement and strengthen its control over the advertising of food, drugs, devices and cosmetics ${ }^{5}$ and, although not included in the Food, Drug and Cosmetic Act, must be regarded as an integral part of food and drug legislation. The Commission's jurisdiction over false advertising in other industries is predicated upon its general authority over "unfair methods of competition"8 and "unfair or deceptive acts or practices," and not, as in the case of food, drug and cosmetic advertising, on any specific enactment.

t Grateful acknowledgment is made to my heavy indebtedness to Lawrence R. Eno, Esq., of the New York Bar for his invaluable assistance in the preparation of this article.

- A.B., I924, LL.B., I926, Columbia University. Member of the New York Bar. Associate Professor, Columbia University School of Law. Adviser to the Secretary of Agriculture in the drafting of the food, drug, and cosmetic bill (S. I944) introduced by Senator Copeland of New York in the 73d Congress, First Session, 1933. General Counsel, National Labor Board, 1933-1934. Special Assistant to the Attorney Gencral, 1933-1934, 1937-1938. Author of casebooks on Vendor and Purchaser (1933) and Trade Regulation (1937). Contributor of numerous articles to legal periodicals on subjects relating ta false advertising and other problems in the field of trade regulation.

${ }^{1}$ Pub. No. 717, 75th Cong., 3d Sess. (June 25, 1938) c. 675, 52 Stat. 1040 (1938), 21 U. S. C. A., c. 9 (Supp. 1938), hereinafter cited as "FD \& C Act."

34 STAT. 768 (1906), 21 U. S. C. \$I, hereinafter cited as "F \& D Act."

"Federal Trade Commission Act, 38 STAT. 717 (1914), 15 U.S. C. $\$ 41$, hereinafter cited as "FTC Act."

'Pub. No. 447, 75th Cong., 3d Sess. (March 2I, I938) c. 49, 52 Star. III (1938), I5 U. S. C. A., c. 2 (Supp. 1938), hereinafter cited as "FTC Act, as amended." The amending provisions of the WheelerLea Act are contained in but three sections. Reference will be made herein to the section numbers of the amended act rather than those of the amending act.

$B$ The advertising provisions of the Whecler-Lea Amendments, supra note 4, are applicable only to food, drugs, devices and cosmetics. The definition of food and drugs contained in that law is a clarificaion of the definition contained in the F \& D Act of $1906 \$ 6,21$ U. S. C. $\$ 7$; the definition of devices and cosmetics is new. The definitions in both the Wheeler-Lea Act and the FD \& $C$ Act are identical. FTC Act, as amended, \$15(b), (c), (d), (e), I5 U. S. C. A. \$55(b), (c), (d), (e) (Supp. 1938); FD \& C Act, \$20I (f), (g), (h), (i), 2 I U. S. C. A. $\$ 321(f),(g)$, (h), (i) (Supp. 1938).

-FTC Act, 55,15 U. S. C. $\$ 45$.

7 This new standard of legality has been imported into $\$ 5$ of the FTC Act by the Whecler-Lea Amend- 
The efficacy of legislation curbing false advertising is dependent upon three factors: (I) the adequacy of its definition of the offense; (2) the effectiveness of the penalties imposed; and (3) the efficiency of the methods of administration established. The Wheeler-Lea Act will be appraised in this article in terms of these factors.

\section{Definition of Offense}

A false advertisement, under the new law, is "an advertisement, other than labeling, which is misleading in a material respect; and in determining whether any advertisement is misleading, there shall be taken into account (among other things) not only representations made or suggested by statement, word, design, device, sound, or any combination thereof, but also the extent to which the advertisement fails to reveal facts material in the light of such representations or material with respect to consequences which may result from the use of the commodity to which the advertisement relates under the conditions prescribed in said advertisement, or under such conditions as are customary or usual," ${ }^{\prime \prime}$ The statute forbids the dissemination of any false advertisement by the United States mails, the circulation of such advertisements in interstate commerce, or their circulation in intrastate commerce if they are likely to induce, directly or indirectly, the purchase in interstate commerce of food, drugs, devices or cosmetics. ${ }^{9}$

How adequate is this definition? Does it include conduct which might better be excluded and contrariwise, does it exclude acts which should be prohibited? This can best be determined by a brief consideration of previous efforts and experience in curbing false and misleading advertising.

False advertising is actionable at common law under varying conditions and circumstances. ${ }^{10}$ A representation of fact in an advertisement, known to be false, which is intended to induce the purchase of the product advertised and which does in fact

ments. FTC Act, as amended, 55, 15 U. S. C. A. \$45 (Supp. 1938). See Handler, New Standard of Legality under Amended Trade Commission Act, C. C. H. Trade Reg. Comments No. 1, June, 1938.

The Commission derives its authority over false advertising in the food and drug field not only from the advertising provisions of the Whecler-Lea Amendments but also from the general grants of power in 55 of the FTC Act, 15 id. 545.

${ }^{3}$ FTC Act, as amended, 515 (a), 15 U. S. C. A. 555 (a)! (Supp. 1938). This section is to be read in conjunction with the FD \& $\mathrm{C}$ Act. In that law, a label is defined as "a display of written, printed, or graphic matter upon the immediate container of any article; and," where information is required to appear on the label, it must also appear "on the outside container or wrapper, if any there be, of the retail package of such article, or is easily legible through the outside container or wrapper." FD \& C Act, \$20x(k), 2 I U. S. C. A. $\$ 32 x(\dot{k})$ (Supp. I938). Labeling is defined as "all labels and other written, printed or graphic matter (I) upon any article or any of its containers or wrappers, or (2) accompanying such article." Id. $\$ 201(\mathrm{~m}), 21$ id. $\$ 321(\mathrm{~m})$.

-FTC Act, as amended, \$12(a), 15 U. S. C. A. \$52(a) (Supp. 1938). This section is a legislative determination that the intrastate advertisement of an article sold in interstate commerce so affects that commerce as to be subject to federal control. The solicitation of interstate sales is a part of interstate commerce. See Crenshaw v. Arkansas, 227 U. S. 389, 396 (1913). Under recent interpretations of the commerce clause there would appear to be little doubt that these regulations fall within the Congressional control over interstate commerce. Jones and Laughlin Steel Co. v. N. L. R. B., 30 I U. S. I (I937); Consolidated Edison Co. v. N. L. R. B., 59 Sup. Ct. 206 (1938); but cf. Schechter Poultry Co. v. U. S., 295 U. S. 495 (1935); Carter v. Carter Coal Co., 298 U. S. 238 (1936); Fisher, The Proposed Food and Drugs Act: A Legal Critique (1933) I Law and Contemporary Problems 74, 107.

${ }^{10}$ Hasdler, False and Misleading Advertising (I929) 39 YALE L. J. 22. 
induce such purchase to the detriment of the buyer, may be made the basis of an action for fraud and deceit.11 Any affirmation of fact or any promise relating to the goods advertised, the natural tendency of which is to induce the buyer to purchase, constitutes an express warranty under the law of sales. ${ }^{12}$ A misrepresentation of fact which diverts custom intended for a competitor may, under one line of authority, be actionable at the suit of such competitor. ${ }^{13}$

False advertising, apart from the new legislation, may entail criminal liability. The advertiser may be prosecuted for obtaining money under false pretences where the buyer is induced to purchase the advertised article on the strength of false and fraudulent representations of fact. ${ }^{14}$ Section 215 of the Federal Criminal Code forbids the use of the mails in the furtherance of schemes and artifices to defraud. ${ }^{15}$ The mails may be closed to the dishonest advertiser by administrative order. ${ }^{18}$ These criminal sanctions, however, have been invoked against flagrant frauds only ${ }^{17}$ and are applicable to fraudulent misrepresentations of fact alone. ${ }^{18}$

II Statements of opinion, seller's puff, and "mere" exaggeration are all excluded from the scope of the action. Handler, supra note io, at 23; cf. RestateMENT, TORTs (1938) \$525.

"Section 12 of the Uniform Sales Act provides: "Any affirmation of fact or any promise by the seller relating to the goods is an express warranty if the natural tendency of such affirmation or promise is to induce the buyer to purchase the goods, and if the buyer purchases the goods relying thereon. No affirmation of the value of the goods, nor any statements purporting to be a statement of the seller's opinion only shall be construed as a warranty." Although this definition dispenses with the scienter requirement of the action for deceit, its exclusion of statements of value and opinion, its restriction to affirmations relating to the goods, and its inclusion of the element of reliance, necessarily limit its utility. Moreover, the doctrine of privity protects the manufacturer whose false statements induce purchases from dealers. WiLLISTON, SaLES (2d ed. 1924) 5244 .

${ }^{23}$ Ely-Norris Safe Co. v. Mosler Safe Co., 7 F. (2d) 603 (C. C. A. 2d, 1925), rev'd, 273 U. S. 132 (1927); Cal. Fruit Canners' Ass'n v. Myer, 104 Fed. 82 (C. C. Md. 1899); Anheuser-Busch Brewing Ass'n v. Fred Miller Brewing Co., 87 Fed. 864 (C. C. Wis. I898); cf. B. V. D. Co., Inc. v. Davega-City Radio, Inc., I6 F. Supp. 659 (S. D. N. Y. 1936). In American Washboard Co. v. Saginaw Mfg. Co., I03 Fed. 28 I (C. C. A. 6th, 1900), a federal court composed of Taft, Lurton and Day, Jj., ruled that a misrepresentation of one's own wares, though resulting in a diversion of trade from a competitor, was not actionable at the suit of such competitor in the absence of trade-mark infringement or passing off. This was modified to a limited extent by the Mosler Safe case, supra. Learned Hand, J., in the lower court, held that a false representation resulting in a diversion of trade was actionable by a competitor. The Supreme Court. however, reversed, ruling in effect that only when the plaintiff is the sole competitor in the field would the action lie. The gravamen of passing off is diversion of trade through a misrepresentation as to the source of one's goods. There is no logical reason why the same injury inflicted by a misrepresentation of a different kind should not ground an action. Even without such diversion of trade, this potent sanction should be available to honest competitors who are unwilling to resort to chicanery in the disposition of their wares and who are subjected to the improper and dangerous competition of the dishonest advertiser. On this problem generally, see Handier, supra note ro, at 34; Handler, Unfair Competition (1936) 21 Iowa L. Rev. 175, 193; Handler, Cases on Trade Regulatton (1937) 723 et seq.

16 Bishop, Criminai Law (9th ed. 1923) \$\$414, 4I5, 449 et seq.

35 STAT. I130 (1909), 18 U. S. C. $\$ 338$; see HaNDLER, Cases on TRADE Reguration (1937) 757.

10 I7 STAT. 322 (1872), 39 U. S. C. \$259; I7 STAT. 323 (I872), 39 U. S. C. \$732.

${ }^{17}$ See Harrison v. U. S., 200 Fed. 662, 666 (C. C. A. 6th, 1912), referring to $\$ 215$ of the Federal Criminal Code, supra note 15. The Postmaster has generally been accorded a greater latitude and has successfully dealt with less flagrant frauds than those enumerated in the Harrison case. Harris v. Rosenberger, 145 Fed. 449 (C. C. A. 8th, 1906), cert. denied, 203 U. S. 591 (1906); Putnam v. Morgan, 172 Fed. 450 (C. C. N. Y. Ig09); cf. Leach v. Carlile, 258 U. S. 138 (1922).

is It has been held that $\$ 215$ of the Criminal Code, supra note 15 , does not apply to puffs. Faulkner v. U. S., 157 Fed. 840 (C. C. A. 5th, I907); see Harrison v. U. S., supra note I7; Foshay v. U. S., 68 F. (2d) 205, 210, 211 (C. C. A. 8th, 1934), cert. denied, 291 U. S. 674 (1934); cf. American School of Magnetic Healing v. McAnnulty, 187 U. S. 94 (1902). As to other vagaries of construction to which 
A broader definition of false advertising is contained in the "Printers' Ink" statute, in force in many states. ${ }^{19}$ This act makes it a misdemeanor for any person, with intent to sell or to induce the purchase of any article, to make, publish or disseminate any advertisement containing any assertion, representation or statement of fact which is untrue, deceptive or misleading. ${ }^{20}$ Neither scienter nor reliance is an essential element of the statutory offense, but it will be observed that only advertisements containing false, deceptive or misleading representations of fact are condemned.21

Though the Food and Drug Act of rgo6 was without application to advertising, its misbranding provisions are worthy of examination since the definitional problems of misbranding are not different from those of false advertising. A food or drug was deemed misbranded under the 'rg06 Act if its label contained "any statement, design, or device regarding such article, or the ingredients or substances contained therein which shall be false or misleading in any particular. . .."22 In United States v. Johnson, $^{23}$ the Supreme Court held that the statutory prohibition related merely to false statements concerning the identity and quality of drugs and not to professions of therapeutic and curative effects. ${ }^{24}$ In other words, the misbranding provisions of the

these laws are subject, see Durland v. U. S., r6I U. S. 306 (I896); Kaufmann v. U. S., 282 Fed. 776 (C. C. A. 3d, 1922), cert. denied, 260 U. S. 735 (1922); Corliss v. U. S., 7 F. (2d) 455 (C. C. A. 8th, 1925); Knickerbocker Merchandising Co. v. U. S., I3 F. (2d) 544 (C. C. A. 2d, 1926), cert. denied, 273 U. S. 729 (1926).

${ }^{2}$ See Comment (1927) 36 Yale L. J. II55, I157; Printers' INK, June 5, 1924, at 93; id, July 28, 1927, at 25 (bibliography of Printer' Ink articles on the model statute); id. Feb. 6, 1936, at 21; Hawdere, Cases on Trade Regulation, 759.

$x^{0}$ The full text of the statute provides: "Any person, firm, corporation, or association who, with intent to sell or in any wise dispose of merchandise, securities, service, or anything offered by such person, firm, corporation, or association, directly or indirectly, to the public for sale or distribution, or with intent to increase the consumption thereof, or to induce the public in any manner to enter into any obligation relating thereto, or to acquire tite thereto, or an interest thercin, makes, publishes, disseminates, circulates, or places before the public, or causes, directly or indirectly, to be made, published, disseminated, circulated, or placed before the public, in this State, in a newspaper or other publication, or in the form of a book, notice, handbill, poster, bill, circular, pamphlet, or letter, or in any other way, an advertisement of any sort regarding merchandise, securities, service, or anything so offered to the public, which advertisement contains any assertion, representation or statement of fact which is untrue, deceptive, or misleading, shall be guilty of a misdemeanor."

I People v. Clarke, 252 App. Div. I22, 297 N. Y. Supp. 776 (1937); Handler, supra note xo, at 32. The statutes in some states require scienter (e.g., Fus. Comp. GEN. LAws (I927) \$7311) or proof that the misrepresentation was known or reasonably should have been known to be false (e.g., Mass. GEN. LAws (1932) c. 266, \$9r). Some state statutes contain language apparently covering statements of opinion and puffs, as well as affirmations of fact (e.g., Conn. Gen. Star. (1930) \$6375). See Note (1930) 43 Harv. L. REv. 945.

F \& D Act, \$8, 2 U U. S. C. \$9. $\quad{ }^{23} 221$ U. S. 488 (19II).

" From the ambiguous language of Holmes, J., in U. S. v. Johnson, supra note 23, stems the argument that Congress lacks the power to control expressions of opinion even though unfounded. He said (p. 498): "In view of what we have said by way of simple interpretation we think it unnecessary to go into considerations of wider scope. We shall say nothing as to the limits of constitutional power, and but a word as to what Congress was likely to attempt. It was much more likely to regulate commerce in food and drugs with reference to plain matter of fact, so that food and drugs should be what they professed to be, when the kind was stated, than to distort the uses of its constitutional power to establishing criteria in regions where opinions are far apart." That the due process clause probably does not stand in the way of a legislative proseription of representations contrary to a general consensus of informed opinion, see Fisher, supre note 9, 95 ef seq. 
Food and Drug Act were limited, as were the common law and other statutory remedies, to misrepresentations of fact.25

The Commission, proceeding under the Congressional mandate to forbid "unfair methods of competition," falsehoods, including misrepresentation of quality and identity of goods, misrepresentation of business status, misrepresentation of geographical origin, false claim of indorsements, fictitious price reductions and other misleading price claims. ${ }^{27}$ Most of its orders have been concerned with representations of fact, but it has proceeded against misleading statements of opinion, therapeutic claims, exaggerations and ambiguous half-truths. ${ }^{28}$ Its authority to censor expressions which are not technically representations of fact has been questioned by some courts. ${ }^{29}$ In Ostermoor \& Co. $v$. Federal Trade Commission, the court said:

"The time-honored custom of at least merely slight puffing, unlike the clear misrepresentation of the character of the goods, ... has not come under a legal ban."30

A similar view was expressed by the Circuit Court of Appeals in the Raladam case. ${ }^{31}$ Representations as to the scientific character and safety of a tablet advertised as an obesity cure were held to be statements of opinion and not of fact and hence could not be banned. The Supreme Court, on appeal, did not determine this aspect

\footnotetext{
$\approx$ The Sherley Amendment to the Act of 1906 was designed to overcome the effect of U. S. v. Johnson, supra note 23, and to plug the gap that decision created in the law. The Amendment provided that an article shall be deemed misbranded "if its package or label shall bear or contain any statement, design, or device regarding the curative or therapeutic effect of such article or any of the ingredients or substances contained therein, which is false and fraudulent." 37 STAT. 4 I6 (rgr2), 2I U. S. C. \$10. See also cases cited in note 33 , infra, prohibiting labels which, though possibly true, created a misleading impression. See especially U. S. v. 95 Barrels of Vinegar, 265 U. S. 438,443 (1924) where the Supreme Court said: "Deception may result from the use of statements not technically false, or which may be literally true. The aim of the statute is to prevent that resulting from indirection and ambiguity, as well as from statements which are false."

"FTC Act, $\$ 5$, 15 U. S. C. $\$ 45$.

"Handler, The Turisdiction of the Federal Trade Commission over False Advertising (193r) 3r Cor. L. Rev. 527, 553; Handler, supra note 7; Nat. Ind. Conf. Bd., Public Regulation of Compettitue Practices (rev. ed. r929) r27-147.

The Federal Trade Commission decisions contain multitudinous orders of this nature. See, e.g., Walker Medicine Co., I8 F. T. C. D. 16 (1933); Dr. Cheeseman Medicine Co., I8 F. T. C. D. 65 (I933); American College, I8 F. T. C. D. 92 (1933); Dr. Southington Remedy Co., 20 F. T. C. D. 195 (1935); National Remedy Co., 2 I F. T. C. D. 253 (1935); Scientific Shamey Co., 2 I F. T. C. D. 268 (1935). In dealing with therapeutic claims, the Commission often admits on behalf of the respondent the testimony of inexpert consumers who claim to have been cured by the medicine as well as expert evidence. Lay witnesses are not permitted to state conclusions or opinions, but are confined to the facts of their condition pribr and subsequent to taking the "cure." The qualification and examination of experts, and the appraisal of their testimony, is no different from that of trials at law. When expert testimony is required, the Commission generally receives the cooperation and assistance of experts employed in other governmental agencies.

$=$ Raladam Co. v. F. T. C., 42 F. (2d) 430 (C. C. A. 6th, I930), aff'd on other grounds, 283 U. S. 643 (I93I); Ostermoor \& Co. v. F. T. C., I6 F. (2d) 962 (C. C. A. 2d, 1927); see L. B. Silver Co. v. F. T. C., 289 Fed. 985, 990 (C. C. A. 6th, 1923); Proctor \& Gamble Co. v. F. T. C., II F. (2d) 47, 48 (C. C. A. 6 th, 1926). 1935).

${ }^{\infty}$ Szupra note 29, at 963; see Fairyfoot Products Co. v. F. T. C., 80 F. (2d) 684,686 (C. C. A. 7 th,

Supra note 29; but cf. F. T. C. v. Ritholz, C. C. H. TrAde REg. SERv. (Ct. Dec. Supp. 1932-7)

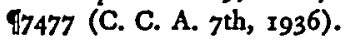


of the decision below. ${ }^{\mathbf{2}}$ On the other hand, in E. Griffiths Hughes, Inc. v. Federal Trade Commission, an order of the Commission prohibiting a representation that Kruschen Salts was a cure or remedy for obesity was sustained despite a conflict of the medical testimony on this point. ${ }^{33}$ Similar orders have been affirmed. ${ }^{34}$

This division of authority raises some doubt whether the Commission, prior to the Wheeler-Lea Act, could forbid advertisements which, though misleading, contain no misstatements of fact. It is not likely that the new grant of jurisdiction to the Commission over unfair or deceptive acts or practices will be held to have effected any change in its powers in this regard..$^{35}$ The new charter was designed to overcome the limiting effects of the Supreme Court decision in the Raladam case which confined the Commission's jurisdiction over false and misleading advertising to those cases in which the misrepresentation was likely to injure honest competitors and thus might be said to be an unfair method of competition. ${ }^{86}$ As the statute is now worded, it is sufficient justification for intervention by the Commission that the advertisement is unfair or deceptive to consumers. ${ }^{37}$ But whether the harmful misrepresentation need be one of fact still remains somewhat uncertain.

This brief review of the prior experience in the suppression of false advertising indicates that the principal definitional difficulties concern the following elements: (I) scienter, (2) reliance, (3) nature of the representation, (4) materiality, and (5) injury.

\footnotetext{
${ }^{2}$ Supra note 29. There is, however, language in the opinion of the Supreme Court evincing a possible disagreement with the lower Court's distinction between fact and opinion (283 U. S. 643, 646). But of. U. S. v. Johnson, supra note 23; American School of Magnetic Healing v. MeAnnulty, supra note 18; Seven Cases of Eckman's Alterative v. U. S., 239 U. S. 510 (1916).

${ }^{3377 . F . ~(2 d) ~} 886$ (C. C. A. 2d, 1935), cert. denied, 296 U. S. 617 (1935). The character of the expert evidence adduced by the respondent was considered unsatisfactory by the Commission. E. Grifiths Hughes, Inc., is F. T. C. D. I (1933).

In Royal Baking Powder Co. v. F. T. C., 4 F. T. C. D. I (rg2r), affd, 281 Fed. 774 (C. C. A. 2d, 1922), an attempt to sell a phosphate baking powder "under an impression" created by prior advertisements of a cream of tartar baking powder was held to be within the Commission's jurisdiction, though the phosphate advertising was literally true. Letters literally true but creating the false impression that customers would receive a free set of books with their purchases were restrained in Consolidated Book Publishers, Inc. v. F. T. C., 53 F. (2d) 942 (C. C. A. 7th, I93I). But see John C. Winston Co. v. F. T. C., 3 F. (2d) 96I (C. C. A. 3d, 1925), vacating an order of the Commission in such circumstances because no "ordinary" purchaser would be misled. Comment (1933) 3I MreH. L. Rev. 804, 815; Fisher, supra note 9, at 88. Cf. the advertising provisions of the Federal Alcohol Administration Act, 49 STAT. 977 (1935), 27 U. S. C. A. $\$ 205$ (f) (Supp. 1938), pertaining to alcoholic beverages. See also cases holding an article misbranded under the $F$ \& D Act of 1906 if a "false impression" was created. U. S. v. American Laboratories, 222 Fed. 104 (E. D. Pa. 1915); Schraubstadter v. U. S. 199 Fed. 568 (C. C. A. 9th, 1912); U. S. v. 95 Barrels of Vinegar, supra note 25 . On the exclusion of puffs from that act, see U. S. V. 94 Dozen Bottles Capon Springs Water, 48 Fed. (2d) 378 (E. D. Pa. 1930), aff'd, 51 F. (2d) 913 (C. C. A. 3d, I931); Fisher, supra note 9, at 82, 83 .

Orders of the Commission forbidding false therapeutic claims in drug advertising have been sustained in several decisions. Fairyfoot Products Co. v. F. T. C., supra note 30; F. T. C. v. Inecto, Inc, C. C. H. Trade Reg. Serv. (Ct. Dec. Supp. I932-7) I7310 (C. C. A. 2d, I935); Dodson and Dodson (Ironized Yeast Co.) v. F. T. C., id. $\$ 7357$ (C. C. A. 6th, 1935); Battle Creek Appliance Co., Ltd. v. F. T. C., id. I7393 (C. C. A. 6th, 1935); F. T. C. v. W. I. Miller (Amber-Ita), id. \{741 I (C. C. A. 6th, 1935); ElectroThermal Co. v. F. T. C., I06 C. C. H. Trade Reg. Serv. $\mid 25,058$ (C. C. A. 9th, 1937). The Commission has consistently and vigorously proceeded against the false advertisement of patent medicines.

"See note 7, supra.

${ }^{\pi}$ It is still necessary that the proceeding be in the public interest. See Handler, supra note 7.
} 
To what extent have these difficulties been overcome in the definitional sections of the Wheeler-Lea Act?

A commendable feature of the new definition is that neither scienter nor reliance is a necessary element of the statutory offense. Any legislation which is confined to fraudulent misrepresentations is virtually worthless. To the duped consumer, the state of mind of the advertiser at the time the misrepresentation was made is of no consequence. It is not the advertiser's subjective intent or knowledge but the fact that his wares are not as represented that causes harm.

The requirement of reliance has proved embarrassing to consumers in invoking those remedies of which it is a constituent element. ${ }^{38}$ The impressions engendered by a skilful advertising campaign may linger long after a particular misstatement has been discontinued. Reliance is an inconsequential element where the purpose of the prohibition is to deter false advertisements and not to compensate aggrieved consumers for loss suffered. To introduce the element of reliance or the likelihood of reliance in an offense which is to be enforced by a public agency and not by private suit is to raise an extraneous and difficult factual issue, provocative of endless and fruitless debate at the trial.

Although the Wheeler-Lea Act omits the element of reliance from its definition of false advertising, it is possible for the requirement to be imported into the statute in the guise of judicial construction of the word "material."38 The statute is violated only when the advertisement is misleading in a "material respect." Can it be said that an advertisement is misleading in a material respect in the absence of evidence that the misrepresentation induced customers to purchase the product or that there is a strong likelihood that the misrepresentation will have this effect? On the other hand can any representation upon which consumers actually rely be said to be immaterial? There are indubitable differences between the concepts of materiality and reliance, but it is not to be overlooked that one of the tests of materiality is whether the representation has or is likely to induce consumers to purchase the product. Materiality being tested by reliance, a possible coalescence of the concepts is not an idle fear. There are some intimations in the cases that if a statement in an advertisement is so fantastic as to be incredible it cannot tend to deceive the public or be the responsible cause of any purchase. ${ }^{40}$ The Restatement of Torts assimilates the element of materiality with the requirement of reliance. ${ }^{41}$ " $(\mathrm{I})$ Reliance upon a fraudulent misrepresentation of fact in a business transaction is justifiable if, but only if, the fact misrepresented is material. (2) A fact is material if (a) its existence or nonexistence is a matter to which a reasonable man would attach importance in determining his choice of action in the transaction in question [i.e., a fact is material

\footnotetext{
\$ See Handler, supra note Io, at 23 et seq.

${ }^{80}$ FTC Act, as amended, $\$ 15(2)$, 15 U. S. C. A. \$55(a) (Supp. 1938). On materiality, cf. Brown Fence \& Wire Co. v. F. T. C., 64 F. (2d) 934,936 (C. C. A. 6th, I933).

${ }^{20}$ See State v. Massey, 95 Wash. 1, 3-4, I63 Pac. 7, 8-9 (I917); John C. Winston Co. v. F. T. C., supra note 33, at 962; cf. Berkey \& Gay Furniture Co. v. F. T. C.s 42 F. (2d) 427 (C. C. A. 6th, 1930). These cases seem to measure the falsity of a statement by its capacity to deceive intelligent purchasers. But $c f$. note 43 , infra.

4 Restatement, Torts (1938) $\$ 538$.
} 
if a reasonable man would rely upon it and a reasonable man is justified in relying on a fact only if it is material], ${ }^{42}$ or (b) the maker of the representation knows that its recipient is likely to regard the fact as important although a reasonable man would not so regard it." In other words, under this rule, a statement in an advertisement is material only if it is of such importance that it may be said to be the inducing cause of the purchase of the advertised wares by reasonable persons, or unless it can be proved that the advertiser knew that the persons to whom the advertisement is addressed would unreasonably regard its statements as important.

How unfortunate it would be were the phrase "material respect" in the WheelerLea Act to be construed in this wisel False advertising laws are designed to protect the weak, the infirm, the unwary, the easily duped, even the fool. How alien to the colorful conditions of the market place is the legalistic and artificial concept of the "reasonable man!" Would a reasonable person "attach importance" to a widely disseminated claim that the $X$ soap will give dowagers the complexion of a schoolgirl or that the $Y$ dentrifice will restore the pristine whiteness of teeth long yellow with age and decay? There would be little need for advertising legislation and other forms of consumer protection if the advertiser made his appeal to "reasonable men." It is because consumers are unsophisticated, because they unreasonably attach importance to baseless claims, because they are lured by exaggerations, half-truths, ambiguities and emotional appeals-in short because consumers do not always act either wisely or reasonably - that legislative protection is required. If a statement is important enough to be included in an advertisement, it is important enough to be true. The advertiser should be credited with sufficient business acumen not to waste valuable space on statements which serve no function. If he feels that they serve some purpose, who is to gainsay him?

It is doubtful, however, that this unfortunate phrase will have the baleful effect presaged by the Restatement definition of materiality.8 Nevertheless, being an elastic term which is capable of infinite expansion and contraction, its presence in the new law detracts from its effectiveness and introduces an unnecessary element of uncertainty. The way is open for any hostile court to emasculate the statute by a stringent definition of materiality. ${ }^{44}$

An uncompromising standard of truth is sometimes thought to be too Olympian for the clay-footed advertiser. "Reasonable latitude must be conceded to the salesman and advertiser in boosting his own product."15 It is this defeatist attitude which is responsible for previous failures in preventing false advertising. It assumes that mis-

Author's insertion.

Cf. F. T. C. v. Standard Education Society, 302 U. S. 112,116 (1937), where the Court said: "The fact that a false statement may be obviously false to those who are trained and experienced does not change its character, nor take away its power to deceive others less experienced. . . Laws are made to protect the trusting as well as the suspicious."

"Seller's puff and statements of opinion may be classed as "immaterial" and thus excluded from the statutory definition.

*H. R. Rep. No. 1613, 75th, Cong, ist Sess. (1937) 4. But of. the advertising provisions of the Federal Alcohol Administration Act, 49 STAT. 977 (1935), 27 U. S. C. A. 5205 (f) (Supp. 1938). 
representation is so inveterate a habit that total prohibition would be impracticable. Hence the field of "immaterial representations" must be left open to the careless and false advertiser while the law concentrates on the purification of material representations. The importance of a representation might be a factor in determining the degree of punishment to be meted out to the derelict advertiser, but to predicate the prohibition itself on the importance of the falsehood is to open the door to chicanery and deceit and to rob the law of most of its force. False advertising can only be eliminated by a prohibition of all falsity, material or immaterial. The cumulative effects of many minor falsehoods can be just as lethal as a single large dose.

In this respect the Wheeler-Lea Act represents a retrogression rather than any advance. The Act of $x 906$ in forbidding mislabeling contained no such qualification. It condemned the inclusion in the label of any statement concerning the product or its ingredients which was false or misleading "in any particular." 8 . The same test is applied in the new Food, Drug and Cosmetic Act. ${ }^{47}$ It is to be deplored that the same language was not employed here. Nevertheless, sympathetic construction by the courts can reduce to a minimum the dangers of this weasel phrase and narrowly restrict its scope.

Unlike some of the previous definitions, there is no qualification of the misrepresentation prohibited by the Wheeler-Lea Act. Under the law of warranty, the affirmation must relate to the goods advertised. ${ }^{48}$ The statements forbidden by the misbranding provisions of the Act of 1906 must pertain to the product or its ingredients. ${ }^{49}$ The amended Federal Trade Commission Act prohibits material misrepresentations whether or not they refer to the article advertised. The omission of any qualification is salutary since it dispenses with extraneous requirements of proof which may impede the enforcement of the statute.

The most serious defect in prior definitions has been the restriction of the prohibition to misrepresentations of fact. The skilful advertiser can mislead the consumer without misstating a single fact. The shrewd use of exaggeration, innuendo, ambiguity and half-truth is more efficacious from the advertiser's standpoint than factual assertions. Facts are dull and dangerous; exaggerations are vivid, attractive and privileged. Any advertising legislation which leaves uncontrolled statements of opinion, puffs, exaggerated claims or ambiguous assertions imposes no real curb upon the dishonest advertiser. Indeed, a prohibition applicable to factual misstatements alone encourages the resort to statements of opinion cunningly contrived to create the semblance of factual assertions. In an earlier article I posed the issue in the following terms: ${ }^{\text {so }}$

"If such statements as, "these second hand tires are as good as new,' 'this suit of clothes will wear like iron,' 'these bicycles are unsurpassable, having been subjected to severe and

¿See p. 94, supra.

"This statute provides that a food shall be deemed to be misbranded "if its labeling is false or misleading in any particular." $\$ 403$ (a), 2 I U. S. C. A. $\$ 343$ (a) (Supp. 1938). Similar provisions apply to the misbranding of drugs and devices, $\$ 502(a), 21$ id. $\$ 352(a)$, and the misbranding of cosmetics, $\$ 602(a)$, 2rid. $5_{3} 62(2)$.

See p. 94, supra.

- See note 12, supra.

${ }^{\circ}$ Handler, supra note 10, at 25. 
practical tests; we are in a position to guarantee them to be all that is claimed for them, perfect of their kind,' or, 'this article will give first class satisfaction, it is the best upon the market, it will sell like hot cakes and will be the best drawing card ever handled,' are regarded as puffs, then all the copy writer has to do is to give free rein to his fancy and avoid conveying any useful information about the article."

Any exemption of puffs or opinion is especially serious in the field of drug advertising, which consists in large measure of therapeutic claims. To make any statutory prohibition applicable to such claims involves some conceptual difficulty. Under what circumstances can it be said that an expression of opinion is false? At common law there was liability in deceit for the utterance of an opinion which was not honestly entertained, the theory being that the assertion in such circumstances constituted a misrepresentation of a state of mind.51 The Sherley Amendment to the Act of 1906 proceeded upon a similar theory and forbade the fraudulent assertion of curative or therapeutic effects of drugs. ${ }^{52}$ This amendment, however, proved to be almost a dead letter in view of the extreme difficulty of convincing juries that the defendant was guilty of fraud. ${ }^{53}$

If the requirement of fraud is abandoned, what is the criterion of the falsity of an opinion? Suppose a manufacturer honestly believes that his brown syrup will cure scarlet fever and has tried it upon his intimates with what appears to be some success? Is not the element of truth an alien criterion to be applied to statements of opinion? An opinion may be honest or dishonest but not true or false. This, in any event, is the contention of those who feel that there are legal and constitutional objections to any regulation of expressions of opinion which are not fraudulent. ${ }^{54}$ I do not share this view. A statement of opinion may or may not have any scientific basis. It may not be possible to establish its truth or falsity with the same ease or objectivity as statements of fact. It is not impossible to show that a therapeutic claim is at variance with the general consensus of informed and scientific opinion. 55 Until the scientific world is convinced of the soundness of the claim, it ought not to be broadcast. The consumer reading of the professed curative effects of a drug naturally feels that there is scientific support for the advertiser's assertion. Unless there is such support, the claim ought not to be made and should be forbidden. ${ }^{56}$ Where re-

\footnotetext{
3 Harper, Torts (I938) \$220.

See note 25, supra.

a Report of the Food and Drug Administration (U. S. Dept. of Agr., Aug. 28, 1933), quoted in Handler, Cases on Trade Regulation, 796 et šeq.

See note 24, supra. The committee of the House of Representatives were evidently troubled by this aspect of the problem. They felt that the cases in the Supreme Court forbade penalizing the publication of claims on which qualified opinion was in disagreement. They therefore inserted a qualification in the definition of false advertising excluding such representations provided the fact of such difference of opinion was stated in the advertisement. If not so stated, the government was evidently still faced with the same difficulties as had theretofore existed. H. R. REP. No. I6 $\mathrm{I}_{3}$, supra note 45, at \%. This provision was eliminated as "unnecessary" in the Conference Report. H. R. REP. No. 1774, 75th Cong., 3d Sess. (1938) 1o. The whole subject was handled in a muddled and confusing manner.

${ }^{\circ}$ See Fisher, supra note 9, at 95.

S. 1944, 73rd Cong., Ist Sess. (1933), a proposed amendment to the Act of xgo6, forbade in 59 (b) (2), "any representation, directly or by ambiguity or inference, concerning the effect of such drug which is contrary to the general agreement of medical opinion." The effect of the new proposal was to modify the Sheriey Amendment, supra note 25, by omitting the words "and fraudulent" and making
} 
spectable scientific opinion is in disagreement, perhaps some concession might be made to the advertiser. For myself, I would prefer a more rigorous standard. Experimentation should be confined to non-human guinea pigs. Conservatism in the scientific world may occasionally deprive the public and delay the acceptance of important discoveries. This loss is more than overbalanced by the immense social harm resulting from undisciplined and unsupported expressions of curative claims.

That the advertising profession appreciates the inadequacy of any definition which is confined to statements of fact is attested by its own formulation of improper advertising practices. The Association of National Advertisers and the American Association of Advertising Agencies in 1932 declared that: ${ }^{57}$

"The following copy practices are unfair to the public and tend to discredit advertising.

"x. False statements or misleading exaggerations.

"2. Indirect misrepresentation of a product, or service, through distortion of details, either editorially or pictorially. ...

"5. Price claims that are misleading.

"6. Pseudo-scientific advertising, including claims insufficiently supported by accepted authority, or that distort the true meaning or application of a statement made by professional or scientific authority.

"7. Testimonials which do not reflect the real choice of a competent witness."

The Fair Practice Code of the National Association of Better Business Bureaus contains the following provision: $: 8$

"I. No statement or representation shall be used in advertising which has the capacity or tendency to mislead or deceive the consumer. This shall include generalizations and implications."

The Advertising Index Expurgatorius of the New York Times bans "advertisements that make false, unwarranted or exaggerated claims"; "advertisements that are ambiguous in wording and which may mislead"; "advertising that makes remedial, relief or curative claims, either directly or by inference, not justified by the facts or common experience." 59

Although the Wheeler-Lea Act is not in terms limited to statements of fact, it is by no means clear how much beyond the prohibition of factual misrepresentations it goes. Its precise language will bear repetition and careful scrutiny at this point:

". . . in determining whether any advertisement is misleading, there shall be taken into account (among other things) not only representations made or suggested by statement, word, design, device, sound, or any combination thereof, but also the extent to which the advertisement fails to reveal facts material in the light of such representations or material with respect to consequences which may result from the use of the commodity to which the advertisement relates under the conditions prescribed in said advertisement, or under such conditions as are customary or usual." 80

every misrepresentation contrary to the general agreement of medical opinion a violation of law. See Fisher, supra note 9, at 95.

"Sce Kenner, The Fight for Truth in Advertising (1936) 288.

${ }^{\infty} 7 d .286-7$.

${ }^{50}$ Quoted in Handler, supra note ro, at 47 n. 7 r.

${ }^{\infty}$ FTC Act, as amended, $\$ 15$ (a), 15 U. S. C. A. $\$ 55$ (a) (Supp. 1938). 
What does this provision mean?

It is clear that under this definition an advertisement may be deemed misleading even though the statements of fact it contains are not in and of themselves deceptive. The statutory ban applies to that which is suggested as well as that which is asserted. ${ }^{61}$ Half-truths as well as the concealment of material facts appear to be forbidden. An advertisement may be misleading not by reason of anything contained in it but as a result of the failure to disclose the consequences that may be anticipated under the suggested or normal conditions of use of the article advertised. In other words, if a drug may be injurious to health under the normal conditions of use, appropriate warnings must be given. Whether warnings would be necessary where an article might be harmful under normal conditions of use to persons suffering from certain allergies is not clear.

The exact limits of the application of the law to exaggerated claims, puffs, therapeutic claims and statements of opinion remain a matter of conjecture in view of its ambiguous phraseology. The test to be applied in justifying a statement of curative effects is left unexpressed. One can only speculate in attempting to mark the boundaries of the new prohibitions. The language may be broadly interpreted to embrace any advertising matter whatsoever which creates a misleading impression in the mind of the ordinary purchaser. On the other hand, the section can be read with scriptural exactitude and confined to the more blatant frauds and falsehoods. The fate of the definition lies with the Commission in the first instance and ultimately with the courts.

The statute does not demand proof of injury to competitors or consumers, a requirement which has hampered previous regulations of false advertising. ${ }^{62}$

A different standard is applied to drug advertising disseminated exclusively to members of the medical profession. Such advertising is deemed to be false only if it contains a false representation of a material fact and is not accompanied by truthful disclosure of the formula showing quantitatively each ingredient in the drug. ${ }^{08}$ In other words, where there is such disclosure and an abstinence from downright falsehoods, misleading impressions otherwise engendered are immune from attack. While a difference in standard may be justified, it is by no means clear why misleading impressions should be tolerated even when advertising is addressed to a sophisticated medical audience.

Two further defects in the Wheeler-Lea Act must be noted. Experience teaches

ander the common law, the failure to reveal facts material in light of the representations made grounded an action for fraud and deceit in some circumstances. HARPER, Torts (1938) \$219; RestATEMENT, TORTS (1938) \$529. Cf. U. S. v. 95 Barrels of Vinegar, supra note 25.

"Handler, supra note 7; see note II, supra.

The FTC Act, as amended, $\$ 15$ (a), 15 U. S. C. A. $\$ 55$ (a) (Supp. 1938), provides: "No advertisement of a drug shall be deemed to be false if it is disseminated only to members of the medical profession, contains no false representation of a material fact, and includes, or is accompanied in each instance by truthful disclosure of, the formula showing quantitatively each ingredient of such drug." Under this definition, an advertisement of a drug disseminated to the medical profession containing no material misrepresentation of fact must still be accompanied by a true disclosure of the formula to be excluded from the statutory prohibition. 
that the problem of false advertising cannot be solved by the mere suppression of falsehood. The consumer suffers not only from deceptive copy but from the failure of advertisers to furnish him with the precise information essential for intelligent consumption. The new law is singularly deficient in not compelling full disclosure of such pertinent information. ${ }^{84}$

No direct effort is made to outlaw the common and notorious therapeutic claims made in patent medicine advertising. Many nostrums are advertised as remedies for diseases for which there is no known specific and for which general medication is concededly useless. An express prohibition of such claims, founded as it would be on common and scientific experience, would materially facilitate the enforcement of the law and would obviate the need for protracted trials to establish in each case that such claims are unsupportable. ${ }^{65}$ Only by crystallizing experience into specific statutory or administrative prohibitions can real progress be made in the elimination of false and misleading advertising.

\section{Adeouacy of Penalties}

False and misleading advertising may be prohibited under the new statute in three ways:

1. The Commission may issue a cease and desist order ${ }^{66}$

2. The Commission may under certain circumstances bring suit in any District Court to restrain the dissemination of the advertisement; ${ }^{67}$

\section{Criminal proceedings may be instituted in certain limited cases. ${ }^{68}$}

The statute effects various changes in the "cease and desist" procedure of the Commission. ${ }^{69}$ The modified procedure may be briefly described as follows: Whenever the Commission has reason to believe ${ }^{70}$ that any person is disseminating or

Disclosure of some information on labels is required by the new FD \& C Act (Food: \$403, $21 \mathrm{U}$. S. C. A. $\$ 343$ (Supp. I938); Drugs and Devices: \$502, 21 id. \$352; Cosmetics: \$602, 21 id. \$362). The affirmative disclosure of pertinent information is required in the advertising of alcoholic beverages. Fed. Alcoholic Adm'n Act, supra note 45.

“S. I944, supra note 56 , in $\$ 9$ (c) provided that, to discourage the advertisement of drugs for diseases wherein self-medication was especially dangerous or patently contrary to the interests of public health, any advertisement of a drug representing it directly or by ambiguity or inference to have any effect in the treatment of some 36 enumerated diseases, ranging from albuminuria to whooping cough, shall be deemed to be false, unless disseminated to members of the medical or pharmacological profession only. Provision was made for alteration of the list, either by increasing or decreasing the index, to conform to the growth of scientific knowledge.

${ }^{\circledR}$ FTC Act, as amended, $\$ 5$ (b), I5 U. S. C. A. $\$ 45($ b) (Supp. I938). In $\$ 12(b)$ it is provided that the causing to be disseminated or dissemination of any false advertisement shall constitute an unfair or deceptive act or practice within the meaning of $\$ 5(\mathrm{a})$. Id. $\$ 12(\mathrm{~b}), 15 \mathrm{id}$. $\$ 52(\mathrm{~b})$. The sanctions relating to the methods, practices and acts forbidden by $\$ 5$ (a) are thereby made applicable to false advertising.

${ }^{o}$ Id. $\$ I_{3}(\mathrm{a}), \mathrm{I}_{5}$ id. $\$ 53(\mathrm{a})$.

${ }^{\infty}$ Id. $\$ 14(a)$, I5 id. $\$ 54(a)$.

${ }^{\infty}$ Id. $\$ 5(b), 15$ id. $\$ 45(b)$.

A case be the basis of its own investigation or as the result of a complaint A case commonly originates through an informal complaint of a consumer, competitor, trade association or consumers' organization. A thorough preliminary investigation of the complaint is conducted by the Commission before further proceedings are undertaken. This may involve a field investigation and a consideration of the facts by the examiners of the Commission. The Commission passes upon the report of the chicf examiner and determines by majority vote whether a formal complaint should issue. All complaints are prepared by the office of the Chief Counsel. 
causing to be disseminated any false advertising of food, drugs, devices or cosmetics, ${ }^{71}$ and it appears to the Commission that the institution of a proceeding would be in the public interest, it may issue a complaint setting forth the charges against the advertiser. A hearing may be had any time after the expiration of a period of thirty days from the date of service of the complaint. Hearings are generally held before trial examiners who render an intermediate report. The Commission considers the case on the basis of the record before the trial examiner. An opportunity for oral argument is extended the respondent. After argument, the Commission renders a decision consisting of findings of facts and an order to cease and desist from the unfair or deceptive practice. Court review of the Commission's order may be had within a period of sixty days. If no court review is sought, the order becomes final at the end of the sixty-day period. The time at which the order becomes final in the event of court review is specified with great particularity. ${ }^{72} \mathrm{~A}$ violation of an order after it has become final is punishable by a civil penalty of not more than $\$ 5,000$ which may be recovered in a civil action by the United States. ${ }^{73}$

Prior to the recent amendments, an order of the Commission became final only after affirmance by the courts. It could be violated with impunity at any time prior to such affirmance. ${ }^{74}$ In some instances, an order of affirmance would be granted only on proof of violation of the Commission's ruling. ${ }^{75}$ This in effect required proof

${ }^{7}$ False and misleading advertising is scrutinized by the "Radio and Periodical Division" of the Commission. It reviews the advertising sections of newspapers and periodicals, advertising copy broadcast over the radio, and receives complaints. If a periodical or radio advertisement appears on its face to be deceptive, this Division conducts an informal examination, on the basis of which it submits a recommendation to the Commission. The matter may be referred back to the Division by the Commission with instructions to negotiate a stipulation. If-no stipulation is executed, formal proceedings are begun.

${ }^{22}$ FTC Act, as amended, $\$ 5(\mathrm{~g})$, I5 U. S. C. A. $\$ 45(\mathrm{~g})$ (Supp. 1938), provides that a cease and desist order shall become final (a) if no petition for review is filed within 60 days after the service of the order, (b) upon the expiration of the time allowed for filing a petition of certiorari, if the order has been affirmed by a circuit court of appeals or the petition for review dismissed, (c) upon a denial of a petition for certiorari under the same conditions, or (d) upon the expiration of 30 days after the issuance of the mandate of the Supreme Court if such Court directs that the order be affirmed or the petition for review dismissed. $\$ \$ 5(h)(i)$ and $(j)$ provide the time within which the order of the Commission shall become final if it is modified or set aside or if a rehearing is ordered. The time when the Commission may modify or alter its own cease and desist order is provided for in $95(b)$.

${ }^{3}$ Id. $\$ 5(1)$, is id. $\$ 45(1)$. The deterrent effect of the provision for a civil penalty is questionable. The penalty can be invoked only when the order of the Commission has become final. By fixing only a maximum fine, a large range remains within which the court can fix a lower penalty. The tendency in most cases has been for the courts to treat offenders of the food and drug laws leniently, and that attitude may well continue.

"Under the original FTC Act, although a respondent could secure judicial review of an order of the Commission at any time, the Commission could resort to the courts only if the respondent failed or neglected to obey the order. FTC Act, $\$ 5,15$ U. S. C. $\$ 45$. If the respondent took an appeal from the Commission's order or the Commission went into court after a violation had occurred and the order was affirmed, the order of the court was equivalent to an injunction. Any punishment was for violation of the court's order and not strictly for violation of the order of the Commission. The Commission requires that when an order to cease and desist has been issued or a stipulation signed, the respondents file within 60 days a report with the Commission setting forth in detail the manner and form in which they have complied with the order or stipulation. Where the order prevents the false advertisement of a food, drug or cosmetic that may be injurious to health, an interim report must be filed within Io days stating how the respondents intend to comply. The Commission may in its discretion require further reports of campliance from time to time. F. T. C., Rules of PrActice, Rule XXII.

${ }^{75}$ In F. T. C. v. Standard Education Society, I4 F. (2d) 947 (C. C. A. 7th, 1926), \$5 of the FTC 
of at least two violations, one before the issuance of the Commission's order and one thereafter. The cumbersome and dilatory nature of this procedure substantially impaired its effectiveness.

Will the modified procedure deter the dissemination of false advertising ? ${ }^{76}$ The Commission must undertake a preliminary investigation before issuing a complaint in order to satisfy itself that grounds exist for the institution of proceedings. This naturally takes time. Hearings cannot be held sooner than thirty days after service of the complaint. Various jurisdictional requirements, such as proof of interstate commerce, tend to prolong the trial. The examiner must take the matter under advisement and prepare his report. The case is then put on the Commission's calendar for argument. After argument, findings of fact and a cease and desist order must be prepared. Sixty days must then elapse before the order becomes binding. ${ }^{77}$

In the meantime the advertiser may have discontinued the challenged advertisement and may have embarked upon a new advertising campaign which is equally deceptive. The proceedings before the Commission may therefore relate to a controversy which has become essentially moot. A cease and desist order does not penalize the advertiser for his previous derelictions and does not prevent him from indulging in new and different misrepresentations. ${ }^{78}$ This procedure thus permits an unscrupulous advertiser to "play fast and loose" with the Commission. He can reap the profits of his misrepresentations until compelled to desist, and then by adopting new copy, continue his depredations of the public until again forced to stop. A prohibition which operates prospectively, and then only after the lapse of considerable time, cannot have much deterrent effect on wrongdoing.

The Commission some years ago inaugurated the practice of settling minor advertising violations by stipulation. Informal conferences are held with the Director of the Radio and Periodical Division of the Commission and the advertiser can avoid formal proceedings by entering into a stipulation in which he admits his errors and agrees to discontinue the improper advertising. ${ }^{79}$ These stipulations, however, do not

Act, 15 U. S. C. \$45, was interpreted to mean that the Commission's application for enforcement first presents the question of whether a violation had occurred, a fact which must be proved before the validity of the order could be eonsidered. Cf. F. T. C. v. Balme, 23 F. (2d) 6r5 (C. C. A. 2d, 1928) in which the court held that the question of violation was not to be considered until the order's validity had been established, referring the question of violation to the Commission for a finding of fact on the point. Accord: F. T. C. v. Baltimore Paint and Color Works, 4I F. (2d) 474 (C. C. A. 4th, 1930).

${ }^{70}$ There is no doubt but that the new amendments go a long way in putting teeth into the Commission's orders. The question still remains, however, whether these changes are by themselves sufficient.

$\pi$ The meaning of the word "final" as used in the new statute, supra note 72, raises some question. The purpose of the provision is obviously to make the order of the Commission res adjudicata as to all issues actually decided. In a suit brought by the United States to recover the civil penalty the court may not have the power to inquire into the validity of the order. An attack on the jurisdiction of the Commission may, however, be permitted under the general rule that a judgment rendered without jurisdiction of the subject-matter is a nullity. Cf. Crowell v. Benson, 28.5 U. S. 22 (1932).

"The Commission has issued "omnibus" orders, forbidding not only the false and deceptive statements actually made, but also "any statements of a similar or substantially like false and misleading nature." Sec, e.g., Dr. Southington Remedy Co., 20 F. T. C. D. I95, 204 (I935); Creomulsion Co., Inc., 20 F. T. C. D. 89,96 (1935).

${ }^{7}$ See note 7I, supta; F. T. C., ANNoAl Report (I937) 42. 
rise above the level of gentlemen's agreements. There is no record of any suit being brought in the courts by the Commission for violation of a stipulation. In the event of such violation, the Commission is compelled to issue a formal complaint and follow the ordinary procedure for the issuance of a cease and desist order. The stipulation, which in each case provides that the facts admitted therein may be used in evidence in subsequent proceedings, facilitates the trial but it has no further legal effect. The situation would be different if consent injunctions were to be entered in the courts on the basis of the stipulation. A subsequent violation would then constitute a contempt and entail unpleasant consequences for the advertiser.

The conclusion is inescapable that the "cease and desist" procedure, in and of itself, is an insufficient curb on false and misleading advertising.

The draftsmen of the new law were undoubtedly conscious of these deficiencies in the Commission's procedure. 'They sought, as we have indicated, to strengthen it in numerous ways. In addition, they provided that the Commission might institute a suit for an injunction pending the issuance of a complaint and until final disposition of the case, whenever it has reason to believe that such injunctive proceedings "would be to the interest of the public."80

The injunctive procedure has all the advantages of speed. Improper advertisements can be summarily halted by restraining order. Once obtained, the injunction is a serious deterrent against future violations, which are punishable as contempts. An efficient injunctive procedure puts teeth in a statutory prohibition. ${ }^{81}$

The statute unfortunately places some hampering restrictions upon the use of the injunctive remedy. The Commission may seek a temporary injunction only when such relief "would be to the interest of the public." It would appear offhand that a restraint on any false advertising would be in the public interest. It is possible, however, for this phrase to receive a restrictive interpretation limiting the occasions on which injunctions may be obtained. ${ }^{82}$ Furthermore, an injunction can not be sought independently of a proceeding by the Commission. ${ }^{83}$ If the Commission fails to prosecute its complaint or does not issue a cease and desist order, the injunction presumably lapses. The statutory set-up thus involves an unnecessary duplication of effort. The case must first be heard before the District Court on the application for

so FTC Act, as amended, $\S_{13}$ (a), I5 U. S. C. A. $5_{53}$ (a) (Supp. 1938).

The injunctive machinery has already been invoked in the case of U. S. v. Hartman Wholesale Drug Co., I06 C. C. H. TRADE REG. SERv. I15,034 (D. Ill. I938), involving a weight reducing remedy that contained a dangerous drug. The advertisements failed to state the presence of this drug and, at the suit of the Commission, the defendant was enjoined from disseminating any advertisement to induce the purchase of its remedy.

Similar language in $\$ 5$ of the FTC Act, I5 U. S. C. $\$ 45$, has been interpreted as a substantive limitation on the Commission's jurisdiction (F. T. C. v. Klesner, 280 U. S. 19 (I929)).

${ }^{83}$ Although the statutory language is not clear, the intent apparently is to give the Commission the right to secure the injunction at any time prior to a final disposition of the complaint. The language, however, is susceptible to the interpretation that no injunction can be sought after the complaint is served.

The circuit court may also issue an injunction in a proper case. FTC Act, as amended, \$5(c), I5.U. S. C. A. $\$ 45$ (c) (Supp. 1938), broadens the power of that court by providing that when a petition for review is filed, the court shall have jurisdiction of the proceeding and may issue such writs as are ancillary to its jurisdiction or, in its judgment, are necessary to prevent injury to the public or competitors pendente lite. 
the injunction. It must then be independently tried by the Commission. If the advertiser feels that the injunction was imprudently granted by the District Court, he may presumably take an appeal to the Circuit Court of Appeals. An appeal may also be taken from the final order of the Commission. There are thus two hearings and two appeals. Would it not have been simpler and more effective to have permitted the injunctive processes to be invoked directly and apart from any pending administrative proceeding?

The statute makes it a misdemeanor, punishable by imprisonment not exceeding six months or by a fine of not more than $\$ 5,000$ for a first offense, and by imprisonment of a year and fine of not more than $\$ 10,000$ for a subsequent offense, for any person to disseminate a false advertisement where (a) the use of the article advertised may be injurious to health because of results from such use under the conditions prescribed in the advertisement or under customary conditions of use, or (b) if the violation is with intent to defraud or mislead. ${ }^{84}$ Mention has already been made of the narrowing effect of a requirement of fraud. State legislation involving the element of scienter as well as the Sherley Amendment have proved ineffective. ${ }^{85}$ It is of course useful to have a criminal sanction available for the more flagrant frauds, but its restricted utility must be recognized. The same observations may be made concerning the other limiting conditions of the criminal sections of the statute. In only a small class of cases can it be shown that the advertised product will be injurious to health under conditions that are suggested in the advertisement or that are customary.

Publishers, broadcasting companies, and other advertising media are exempted from the criminal provisions of the statute except where they refuse on request of the Commission to furnish it with the name and post office address of the manufacturer, packer, distributor, seller or advertising agency which placed the advertisement for dissemination. ${ }^{86}$ The disclosure of similar information frees any advertising agency from criminal responsibility ${ }^{87}$ The criminal sanction thus may be limited to the seller of the advertised product, whether he be manufacturer or distributor, despite the fact that the advertising agency or advertising medium may have originated or suggested the improper advertisement.

With these qualifications and exemptions, little can be expected from the criminal provisions of the Act.

\section{Methods of Administration}

The Department of Agriculture is entrusted with the administration of the Food, Drug and Cosmetic Act, ${ }^{88}$ pertaining to misbranding and adulteration, while the Federal Trade Commission is charged with the enforcement of the Wheeler-Lea Act, ${ }^{80}$ dealing with false advertising. An anomalous situation is created by this di-

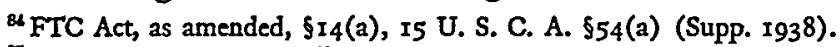

${ }^{\infty}$ See note 53, stupra; Handler, supra note ro, at 28 et seq.

${ }^{\infty}$ FTC Act, as amended, $\$ I_{4}$ (b), 15 U. S. C. A. $\$ 54$ (b) (Supp. 1938).

${ }^{\circ}$ Ibid.

${ }^{B 5}$ FD \& C Act, \$701, 2I U. S. C. A: \$37I (Supp. I938).

"FTC Aet, as amended, 55, 15 U. S. C. A. $\$ 45$ (Supp. 1938). 
vision of enforcement powers. A manufacturer who both misbrands and falsely advertises his product can be prevented only after two proceedings by two separate agencies of government. Unless a formula for close cooperation between the two agencies is devised, uncertainty and confusion will be engendered and a duplication of staffs, investigations and litigation, costly both to the government and the indus. tries regulated, will result. Coordination of the efforts of both agencies through cooperation can, however, to a large extent mitigate the inconveniences arising from this division of responsibility.

The administrative enforcement of any law has the advantage of specialization and permits of a continuity and uniformity of administrative policy. It is preferable to the orthodox delegation of enforcement to overworked prosecuting officials charged with administering numerous unrelated criminal laws. It is frequently impossible for the ordinary prosecutor to find the time to proceed against minor offenses and as a consequence, laws such as these against false advertising tend to become nugatory. A special agency of government, armed with effective sanctions, supplied with a trained personnel and adequate funds, and commanded by vigorous leaders, can make substantial progress against practices even as inveterate and widespread as false advertising.

The Commission, unfortunately, is not armed with effective sanctions. No matter what improvements may be made in its organization, it will be seriously handicapped by the absence of penalties having a real deterrent effect. Nor would it be sufficient to enact amendments imposing such penalties. The magnitude of the problem requires the enlistment of non-governmental agencies of enforcement. By forging suitable remedies for the private litigant, whether purchaser, ${ }^{90}$ competitor, ${ }^{01}$ trade association $^{92}$ or consumers' organization, it is possible to obtain wide and effective assistance in the suppression of an evil which government alone cannot accomplish.

The problem of false advertising must be attacked at its source. It is much more important to prevent the dissemination of false advertisements than to punish the advertiser after publication. The advertising medium is the center of infection. The publisher and broadcasting company owe a definite obligation to the public to prevent the contamination of their columns and channels by false advertising. It is not to be overlooked that the profits of deception flow into their coffers. It is within the power of advertising media to prevent any deceptive advertising.

Prior to the Wheeler-Lea Amendments, the Commission evolved the practice in some cases of joining the publisher with the false advertiser as a party to the proceeding. ${ }^{93}$ Implicit in the new act is the assumption that advertising media are equally responsible with the advertiser. This conclusion is supported by the express exemp-

${ }^{\infty}$ Handler, supra noie 10, at 27.

atd. at $4 \mathrm{r}$.

Handler, Cases of Trade Regulation (1937) 729.

* McGowan Laboratories, Inc. and Womanhood Pub. Co., Ix F. T. C. D. I25 (I927). In some instances the Commission has compelled the publisher or broadcaster to sign stipulations to abide by the Commission's order or stipulation against the false advertiser. Orlando Broadcasting Co., 2r F. T. C. D. II47 (1935); Crowell Publishing Co., 21 F. T. C. D. II5I (1935). 
tion of such media from criminal liability under certain circumstances ${ }^{94}$ and the permissive provisions of the injunctive section, exempting from the operation of any restraining order periodicals already published and about to be circulated, the distribution of which would be delayed by the injunction. ${ }^{95}$ Commendable though this imposition of responsibility may be, ${ }^{88}$ the failure to implement it with suitable penalties impairs its usefulness. Were real sanctions to be imposed upon publishers and broadcasting companies for their failure to exercise due care in preventing their dissemination of false advertising, a vigilant rejection of deceptive copy would be induced. Even under the present procedure múch can be accomplished through "omnibus" orders directed against publishers and broadcasters. ${ }^{97}$ A violation of such orders, once final, will result in liability for the civil penalty. The administration of the statute, however, would have been facilitated by a clearer definition of the responsibilities of the advertising media and the imposition of heavier penalties.

The affirmative disclosure of vital information regarding the product advertised limits the opportunity for misleading assertions and thus reduces the volume of violations to be prosecuted. The bane, when accompanied by the antidote, loses its toxic effect. $I t$ is to be regretted that the opportunity to introduce this feature into the law was not availed of by the proponents of this legislation.

Administration is immeasurably facilitated when general prohibitions are supplemented with specific interdictions. It is much more important to the advertiser to be instructed as to the manner in which his products may be advertised than to be confronted with a blanket denunciation of false and misleading advertising. The Commission should be given the power to promulgate rules and regulations condemning specific improprieties in advertising practice and affording affirmative guidance to advertisers in the preparation of their copy. ${ }^{98}$

A device used by some Better Business Bureaus in their attempts to discourage resort to false advertising has been the publication of compulsory retractions. These statements by the false advertiser note the particulars in which his prior advertisement was false or deceptive and do much to dispel the misleading impressions created by the prior publication. ${ }^{99}$ Would it not be a potent deterrent to vest the Com-

" FTC Act, as amended, \$14(b), I5 U. S. C. A. $\$ 54$ (b) (Supp. 1938). Supre notes 86 and 87.

\%The FTC Act, as amended, $\$ \mathrm{I}_{3}(\mathrm{~b}),{ }_{5}$ id. $\$ 53(\mathrm{~b})$, provides that if the court is satisfied that the restraint of the false advertisement in an issue of a publication published at regular intervals would delay the delivery of the issue after the regular time therefor, that issue shall be excluded from the operation of the injunction, provided that the delay would be caused by the customary manner of manufacturing and distributing and not by any attempt to evade the Act. This section can conceivably form a convenient loophole for many false advertisements. The section seems addressed to the court's "discretion, and it is to be hoped that publications containing advertisements the single appearance of which may work irreparable injury to the public will not be permitted to circulate no matter how great the apparent injury to the publisher.

The statutory language imposing responsibility for the dissemination of false advertising upon the advertising media is by no means clear. That there is such responsibility is implied by the sections

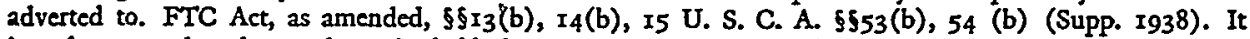
is unfortunate that clear and unmistakable language was not used in this connection.

${ }^{n}$ See note 78, supra.

Cf. the advertising provisions of the Fed. Alcohol Adm'n Act, supra note 45 .

\% Handler, supra note 10, at 46. 
mission with power to compel such retractions, requiring the same publicity for the retraction as was accorded the original advertisement?

Both the original Federal Trade Commission Act and the Wheeler-Lea Amendments are silent as to whether the Commission or the respondent must bear the burden of proof in proceedings thereunder. There is some language in Section 5 of the Federal Trade Commission Act that seems to place the burden on the respondent, ${ }^{100}$ but the Commission has assumed that it has the burden of establishing the allegations contained in its complaints. ${ }^{101}$ There is no hardship in compelling a defendant who has uttered the statement in the first instance and who has peculiar knowledge of the facts, to prove the truth of his assertions, rather than to require proof of falsity by the government. Until one is prepared to support his assertions by evidence, he should desist from proclaiming to the world contentions that are unsupportable. It would not be difficult to formulate a fair and reasonable rule of procedure under which the burden of proof would be more equitably distributed and the ultimate burden of persuasion reposed in the advertiser, who reaps the rewards of his statements.

While the Wheeler-Lea Act represents a sincere attempt to stem the avalanche of false and misleading advertising, it is no more than a first, and unfortunately, inadequate step in that direction. Unless buttressed by clarifying amendments broadening its prohibitions and implementing it with effective sanctions, it will not effect an abiding solution of the vexing problem of false and misleading advertising.

${ }^{100}$ The FTC Act, as amended, 55 (b), 15 U. S. C. A. $\$ 45$ (b) (Supp. 1938), provides that "The person, partnership, or corporation so complained of shall have the right to appear at the place and time so fixed and show cause why an order should not be entered by the Commission requiring such person, partnership,

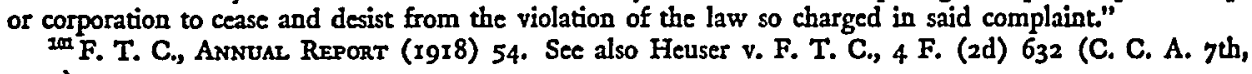
1925). 